\title{
Improving Students' Vocabulary Mastery by Using ESA (Engage, Study, Activate) Method for the Students' of Eighth Grade at MTs Negeri 02 Pekanbaru
}

\author{
Herdi ${ }^{1)}$, Siti Restian Ningsih ${ }^{2)}$ \\ ${ }^{1)}$ Universitas Lancang Kuning \\ herdi@unilak.ac.id \\ ${ }^{2)}$ Universitas Lancang Kuning \\ sitirestian@gmail.com
}

\begin{abstract}
This research was conducted at MTs Negeri 2 Pekanbaru based on phenomenon that most of the students were less vocabulary. The purpose of this research was to improve the students' vocabulary mastery by using ESA (Engage, Study, Activate) method as a teaching method and factor that influence it. The research was a Classroom Action Research. The total number of the sample was 30 students at grade VIII.1 of MTs Negeri 2 Pekanbaru. The researcher did the research in one cycle (five meetings including the test). The data was collected by using vocabulary test, observation checklist, and field notes. There was improvement from based score to cycle 1 . In the based score, noun was 65.32 , verb was 69.32 , adjective 65.32 , and adverb was 66.64 with average score 66.67 . The result of cycle 1 , noun 74.64 , and verb was 81.32 , adjective was 76.64 , and adverb was 82. This research, showed that there were some factors influencing their improvement. The students were engaged in activities, having fun, and active in learning process. The teacher's approach in explaining material was clear enough and classroom condition as well as method supported the learning achievement. After conducting this research by using ESA (Engage, Study, Activate) method improved in cycle 1. Referring to the result, researcher concluded that ESA (Engage, Study, Activate) method can improve the students' vocabulary mastery.
\end{abstract}

Keywords: ESA (Engage, Study, Activate) method and Vocabulary Mastery 


\section{INTRODUCTION}

Vocabulary is one of the basic elements in mastering language skills. Students have many problems in mastering English words. They have limited vocabulary to comprehend the meaning of a text, they could not recognize the meaning of a text, they were not able to hear English words from the speakers and they got difficulty to state some sentences in English, so they became difficult to communicate receptively and productively in English.

Based on the curriculum (2013) of MTs Negeri 02 Pekanbaru, the students were targeted to learned vocabulary mastery. It means that, the students were to be able to learned vocabulary mastery and must be found new words and also knews the meaning of sentences. Based on pratice teaching on $17^{\text {th }}$ July $-17^{\text {th }}$ October 2017 , the researcher found that the students cannot did the exercise from the text book and orally, they did not comprehend a text well because their vocabulary were low. Most of the students got the score below Minimal Completeness Criteria (KKM) of English lesson in MTs Negeri 02
Pekanbaru. The Minimal Completeness Criteria (KKM) apply for grade eight by school is 75 .

Some problems that make the students are difficult to master the vocabulary. The first problem was most of students still have limited vocabulary in English and the students did not practice English in daily conversation. . The second student felt bored with the teachers' way of teaching vocabulary, in which they are asked to found out the meaning of difficult words in the dictionary and then memorize the words. This situation makes them lazy to study English. Considering the importance of vocabulary in learning English and the students' vocabulary mastery, teacher should be able to make the lesson more fun and attractive.

To overcome the students problems above the researcher will applying ESA (Engage, Study, and Activate) as one of alternative to solved this problem. It was one of the method form communicative learning method to improve students interest to study. Harmer (2001:67) "ESA (Engage, Study, Activate) is element which are present in a language 
classroom to help student learn effectively and not bored and scare." In ESA (Engage, Study, Activate) method the teacher tried to improve the students' interest and engage their emotion. This might be through game, the use of picture, audio recording, or video sequence, drama story and amuse anecdote. The aim this method to arise the students' interest, curiosity and attention in lesson sequence.

There were some reason why ESA (Engage, Study, Activate) method was choosen in improveddstudents' vocabulary mastery. According Daharia (2016) conductes the research entitled "Increasing Students' Vocabulary Throug Engage Study and Active Method at the Second Grade of SMP 3 Lembang Pinrang Regency," she found that Using Engage, Study, and Active (ESA) method in teaching could increase the students' vocabulary mastery in using noun and verb, after getting treatment of action research for 2 cycles it was found that the student score is 64 percent in the first cycle and 82 percent in the second cycle. It could be concluded that the use of ESA method in teaching and learning English process can increase the students' vocabulary mastery. ESA (Engage, Study, Activate) method was a method could gave motivated students to study. It give student the chance to rehearse English, as they are doing in their daily life. Second, these method was an effective way for students and the teacher to assess whether the teaching and learning process is success or not.

\section{A. Vocabulary Mastery}

According to Vossoughi (2009:1), Vocabulary is one element of language component that should be learn and taught. Word vocabulary is the tool we use think, to express ideas and feelings, and learn about the world. For the people vocabulary as a basic knowledge to make a communication, and for the students to fulfill their knowledge and conversation which each other.

Vocabulary is a core component of language proficiency and provides much of the basis for how well learner speak, listen, read and write (Richards and Renandya, 2002:26). Vocabulary is a word or a sound which represents a certain meaning as an utterance unity. Vocabulary is the most important part in language learning.

\section{B. Importance of Vocabulary}

Pasty (2006) states that for most people, the importance of vocabulary seems very clear. As it has often been remarked, we can communicate using words that are not placed in the correct order, pronounced perfectly, or marked with the appropriate grammatical morphemes, but communication often breaks down if we do not use the correct words. Although we can use gesture and circumlocution but the vocabulary is very important to use when we communicate. Vocabulary is 
the basic component to help the students in mastering language. They can learn the language skill easily if they have enough vocabulary.

In any foreign language, learning vocabulary is one that is emphasized. Students have to develop their vocabulary. Because with developing a good vocabulary will help them to improve their ability in learning vocabulary. Many of the vocabulary in English textbook have to be learned. Without it no one can speak or understand the language. It means that people cannot write a word or make a sentence well, when they do not master it.

As Alemi and Tayebi (2012:1) states that vocabulary is the basis component of language proficiency which provides the basis for learners' performance in other skill, such as: speaking, reading, listening, and writing. The students who have good vocabulary mastery will have well in other skill and high score on achievement test than students who are lack of vocabulary.

\section{Vocabulary Assessment}

According to Burhan in Permatasari (2011), there are some aspects of vocabulary that can be evaluated:

\section{1) Spelling}

It is important to memorize the letter of vocabulary. The student need to know how spell the words correctly.

2) Pronunciation
This aspect is to know how the students can pronounce the vocabularies that have been learn.

3) Meaning

In learning a foreign language, it is necessary to know the meaning of the word. It is make the students understand what the native speaker means. So, meaning is to know how the students can catch the meaning of the words.

\section{4) Memorizing}

It is to know how many vocabularies that the students can memorize well in the teaching learning process.

\section{ESA (Engage, Study, Activate) Method}

Engage, Study, and Activate (ESA) Method In teaching speaking Teacher should approach to teach material and focusing on learner' needs. According Harmer (2001) Proposed an approach he call ESA (engage, study, activate). In the Engage phase, the teacher make the students' interest and engage their emotion. It can be realized through a game, the use of picture, audio recording, video sequence, or a new/story/ anecdote. In the Study stage the focus is move into the target feature. And in the activate phase the students can apply and can make something from the before phase. Moreover, Tomlinson (2013:238) defines of Engage is about trying to encourage the student to speak, it doesn't matter what about, or oven if it is corrects just to try and get the 
students to use the English language. In the Study phrase, teacher focuses on the main subject of the lesson, explaining themselves and getting the students to participate in some exercises. During Activate stage the students is encouraged to use what they have just learnt in a freer setting, during conversation or games. In this case the ESA as method in teaching vocabulary to make teacher easier to teach students and effective so the students can enjoy in learning.

\section{E. The Nature of Narrative Text Teaching Vocabulary by Using ESA ( Engage, Study, Activate ) Method}

E.S.A is one of teaching method which stands for Engage, Study and Activate. They are phases which are presented in a language classroom to help students to learn effectively which developed by Harmer (2001). The Three Stages of E.S.A. are as follows.

\section{a. Engage}

It is important to engage the students. This stage is very important because in this stage getting the students interested in the subject, in the class and in the language point and can enjoying with they are doing (Robertson and Acklam, 2000). During the Engage phase, the teacher tries to arouse the students' interest and engage their emotions. This can be through a game, the use of a picture, audio recording, a dramatic story, an amusing anecdote, etc. The aim is to arouse the students' interest, curiosity, and attention. This is the point in a teaching sequence where teachers try to arouse the student's interest, thus involving their emotions. As the creator of this method, Harmer (2001) echoes that if students are engaged, if they are genuinely interested and involved in what is going on, the chances are that they are going to learn an awful lot better because the are not just doing what they have to do because they are in school, they are also involved in what is going on.

b. Study

In this phase activities are those which focus on language (or information) and how it is constructed. The focus of study could vary from the pronunciation of one particular sound to the techniques an author uses to create excitement in a longer reading text. Students can study in a variety of different styles: the teacher can explain grammar, they can study language evidence to discover grammar for themselves, they can work in groups studying a reading text or vocabulary. But whatever the style, study means any stage at which the construction of language is the main focus.

c. Activate

This stage describes the exercises and activities which are designed to get students to use the language as communicatively as they can. During Activate, students do not focus on language construction or practice particular language patterns but use their full language knowledge in the 
selected situation or task. The objective for the students is not focus on language construction or practice specific bits of language such as grammar patterns, particular vocabulary items, and functions but for them to use all and any language which may be appropriate for a given situation or topic (Harmer, 2001 and Herdi and Adriana, 2017).

\section{F. Advantages of Engage, Study, and Activate (ESA) Method}

In teaching vocabulary, teacher can apply this method because there are some advantages. Robertson (2000) states that Engage, study and activate (ESA) important. ESA (Engage, Study, Activate) gives students the chance to rehearse English, as if they were doing in the real world but in the safe environment of the classroom. The students can practice their English in the classroom to going in real world later. By giving students this kind of practice, it helps them to think about 'switch' language they have been studying, into language which they can use instinctively. These kinds of activities are often fun and enjoy for the students. Make providing an enjoyable classroom experience for students helps the learning process. Effective way for both students and the teacher to assess how well the class is progressing. Providing suitable tasks which the students can achieve using lots of different language has a positive motivational effect on students.
In short, the advantages of the method is students involve their interest, curiosity, and emotions toward the topic will be taught by teacher, the students felt fun and enjoy in learning. In this case, the teacher should give attention and motivates to students as target learner. Moreover, this method makes students learn about how to demonstrate their opinion, knowledge and language.

\section{G. Factor Influence Students Vocabulary}

According to Mahmoudi

(2008) there are two which influence the student vocabulary :

\section{a. Internal Variables}

Internal variables imply cognitive and affective factors such as motivation, intelligence, anxiety, risk-taking ability, etc. Because of space limitation, only some of these variables are elaborated on here.

Motivation is believed to act as an engine generating learning and then propelling students forward helping them overcome the difficulties they encounter in learning a foreign language (Cheng and Dörnyei, 2007; Dörnyei and Csizer, 1998). Brown (2007) considers motivation as an affective factor that plays a central role in learning a second or foreign language. Cohen (2010) sees motivation as a dynamic 
process that is not stable but is in a continuous change.

Language learners' attitudes toward the language being learned, likewise, can have a significant impact on SLA. Where the community has a broadly negative view of the target language and its speakers, or a negative view of its relations to them, learning is typically much more difficult.

Extraversion and introversion are two personality types that fall within the brief of internal variables. Usually the extraversion better than introverts. Gregarious people usually tend to communicate with others even if they are not sure they will succeed (Kinginger and Farell, 2004).

\section{b.External Variables}

Among external variables one can refer to such variables as social class, first language, teachers, early start, curriculum, etc. environment and curricular is the list of external variable in Generally speaking. Nation and Macalister (2010), for example, in discussing the importance of curricular issues, highlight the importance of needs analysis, sequencing the course materials, evaluation, format and presentation of materials. Richards (2001) too emphasizes the roles of institutions, teachers, and learners in providing for effective learning.

Teacher behavior definitely influences all kinds of learning especially learning a foreign language.
According to Cheng and Dörnyei (2007), teachers can fire students' enthusiasm by being a personal model in the class. Stipek (2002), also points to the importance of the teachers' projection of enthusiasm. With the development of technology the Internet is playing a more and more important role in learning English. English students are downloading English songs, and films that let them get exposure to real English at a globalized communicational level (Nurul Islam, 2011). The Internet is much more than this. All people around the globe, especially students, use it to do research, to access library materials, online quizzes, podcasts, and the like (Khanchali, \& Ziadat, 2011).

\section{METHOD}

This research was a classroom action research. It applied in cycles and it focused on seeking solution to problems of classroom management, instructional strategies, use of materials, or students learning. Burnsin Richards and Farrell (2005) defined that professional development activities such as action research are integrate into school or organizational change as a significant way of facilitating school curriculum renewal and ensuring that language teachers maintain greater ownership of curriculum implementation

The participants was grade eighth student of MTs N 02 Pekanbaru, the researcher took in class VIII.1 of MTs N 02 Pekanbaru. The reason for chose 
this students were the majority of student less vocabulary mastery.

Table 3.1

Participant of the Research

\begin{tabular}{|l|l|l|l|}
\hline \multirow{2}{*}{ Class } & \multicolumn{2}{|l|}{ Participant } & \multirow{2}{*}{ Total } \\
\cline { 2 - 3 } & Female & Male & \\
\hline VIII.1 & 19 & 11 & 30 \\
\hline
\end{tabular}

The instruments used to collect the data. In this research, the researcher used test, observation checklist, field note, and interview.

The researcher hopes that by having the collaboration with the teacher - collaborator, the activities of the researcher and the students during learning process can be observed well.

\section{FINDING AND DISCUSSION}

This chapter presented the description of data analysis. These were done to answer the formulation of the research: "To what extent ESA (Engage, Study, Activate) method can improve the students' vocabulary mastery at grade VIII of MTs Negeri 02 Pekanbaru?" And "What factors influence the changing of students' vocabulary mastery at grade VIII of MTs Negeri 02 Pekanbaru?" both of the formulation of the research were answered based on the data from the vocabulary test, observation checklist, field note and interview.

After analyzing both quantitative and qualitative data, the result showed that there was a significant increasing of the students' vocabulary after the researcher conducted the research. Based on the research findings of this study, it can be concluded that using ESA (Engage, Study, Activate) can gave evidence the students vocabulary mastery increasing at grade VIII.1 MTs Negeri 2 Pekanbaru. The cycle in this classroom action research consisted of four phases; planning the research, implementation the plan, doing the observation and reflecting.

The Average Score of Students Vocabulary Mastery Per Indicator

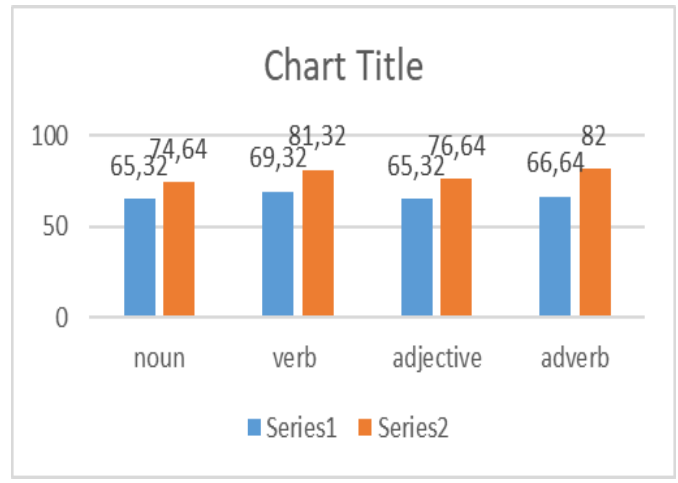

Based on the table and diagram above, it could be seen that the students' vocabulary mastery for one cycle was improved. It showed that the students vocabulary mastery for noun on base score was 65.32 while on cycle 1 was 74,64, and for verb on base score 69.32 while on cycle was 81.32 the students vocabulary for adjective on base score was 65.32 while on cycle was 76.64, and for adverb on base score 66.64 while on cycle was 82 . 


\section{CONCLUSION}

After conducting this Classroom Action Research in improving the students vocabulary mastery at grade VIII.1 of MTs Negeri 2 Pekanbaru by applying ESA (Engage, Study, Activate) method and also from the test, observation, field note, and interview. The researcher concluded this research into some conclusion as follow:

1. Teaching vocabulary mastery by using ESA (Engage, Study, Activate) method can improve the students vocabulary mastery at grade VIII.1 of at MTs Negeri 2 Pekanbaru. It can be see from the achievement of students where the students score of cycle is higher than based score (66.66 in based score and 78.66 in cycle).

2. Teaching vocabulary mastery by using ESA (Engage, Study, Activate) method have some factors can influence the changing of students' vocabulary mastery at grade VIII.1 as below :

a. ESA (Engage, Study, Activate) method make the students easy to understanding the topic. It is because the situation of the class not monotonous and the students enjoy the learning process.

b. ESA (Engage, Study, Activate) method made the students could understand the material easily and also help the students comprehend the material, learning vocabulary different than before. And some of the students which just silent can more active and ask question.

c. ESA (Engage, Study, Activate) method as a media can help them to learn vocabulary and them to be easy comprehend the material well. And the student also can more active, don't afraid and anxiety when their speak English.

\section{REFERENCES}

Alemi, M. \& Tayebi, A. (2012). The influence of incidental and intentional vocabulary acquisition and vocabulary strategy use on learning L2 vocabularies. Journal of Language Teaching and Research.

Arikunto Suharsimi. 2010. Prosedur Penelitian Suatu Pendekatan Praktik. Jakarta: PT. RinekaCipta.

Brown, H.D. (2001). Teaching by Principles: an interactive approach.

(2007) Principles of Language Learning and Teaching $\left(5^{\text {th }}\right.$ ed.) NewYork : Pearson Education, Inc.

Cheng, H., \& Dörnyei, Z. (2007). The use of motivational strategies in language instruction: the case of EFL teaching in Taiwan. Innovation in Language Learning and Teaching, 1(1), 153-174. 
Cohen, A. D. (2010). Focus on language learner: Style, strategies, and motivation. In N. Schmitt (Ed.), An introduction to applied linguistics (2nd ed.). London: Hodder \& Stoughton Ltd.

Daharia, St. Nurjannah Yunus Tekeng. 2016. Increasing Students' Vocabulary Through Engage Study and Active Method at the second Grade of SMP 3 Lembang Pinrang Regency.

Djiwandono, Soenardi.M.(2008).Tes Bahasa (Pegangan Bagi Pengajar Bahasa).Jakarta: PT.Indeks. Herpertiwi.

Donald Ary, Lucy Cheser Jacobs, Christine Knupp Sorensen (2010). Introduction to Research in Education. Publisher, Wadsworth, 2010. ISBN, 0495832510, 9780495832515. Length, 669 pages

Harjali. 2016. The Implementation of Engage, Study, Activate (E.S.A) in Teaching English for Senior High School.8 Jurnal Pendidikan dan Pengajaran, 50 (1), April 2017, 1-9

Harmer, Jeremy. 2007. The Practice of English Language Teaching (4th Ed.). England: Pearson Education Limited.

Herdi, Herdi, and Nelisa Andriana. "A Study on the Students' Ability in
Using Preposition of Direction." ELT-Lectura 4.2 (2017).

Ilinawati, Sudarsono, Regina. 2015. ESA (Engage, Study, Activate) to Improve Teaching Speaking on Job Interview.

Jack C. Richards, Willy A. Renandya.(2002) Methodology in Language Teaching: An Anthology of Current Practice. Edition, illustrated, reprint. Publisher, Cambridge University Press, 2002. ISBN, 0521808294, 9780521808293. Length, 422 pages. Subjects. Education.

Khanchali, M., \& Zidat, A. (2011). The impact of the Internet on the development of students' writing. Revue des Sciences Humaines 21, 51-62.

Kinginger, C., \& Farrell, K. (2004). Assessing development of metapragmatic awareness in study abroad. Frontiers: The Interdisciplinary Journal of Study Abroad, 10, 19-42.

M Mahmoudi, A Simchi, M I mani, AS Milani, P Strove. (2008). The Journal of Physical Chemistry B 112(46), 14470-14481

M. Lightbown, Pasty and Spada, Nina. 2006, How Language Are Learned Third Edition,. Oxford University Press, New York. 
Nation, I. S. P., \& Macalister, J (2010). Language curriculum design. New York: Routledge

Nurul Islam, M. (2011). Independent English learning through the Internet. Journal of Language Teaching and Research, 2(5), 1080-1085.

Pasty and Nina Spada. (2006). How Language are Leraned $3^{\text {rd }}$ ed. Oxford. Oxford University.

Permatasari.(2011). Improving Students Reading Skill of Narative Text by Using Story Mapping Strategy: a Classroom Action Research at the Eight Grade Students of Smp N Undaan Kudus.

Rahman, Abdur. 2015. Teaching Speaking by Using Combining Presentation, Practice, Production (PPP) Method and Engage, Study, Activate (ESA) Method to Improve Students' Speaking Ability at Junior High School.

Richards, J. C. (2001). Curriculum development in language teaching. New York: Cambridge University Press.

Richards and Farrell, 2005. J.C. Richards, T.S.C. FarrellProfessional Development for Language Teachers: Strategies for Teacher Learning.
Stipek, D. J. (2002). Motivation to learn: Integrating theory and practice (4th ed.). Boston, MA: Allyn and Bacon.

Tomlinson, Brian.2013. Applied Linguistics an. Materials Development.

Vossoughi, Hossein. 2009. Using Word-Search-Puzzle Game for Improving. VocabularyKnowledge of Iranian EFL Learners. Journal of Teaching English as a Foreign Language and Literature of Islamic Azad University 